\title{
RISE OF ASIA: IMPLICATIONS FOR EUROPE AND THE UNITED STATES*
}

\section{The Rise is Real}

There appears to be a consensus that Asia is "rising." Much of the change in the decades ahead will relate, of course, to the rise of China and, in China's wake, the rise of India. They add to Asia's already substantial share in the world economy and, within little more than a decade or so, that will make Asia the largest centre of world output and trade of any region in the world - bigger than North America, and bigger than all of Europe.

In the past 20 years, China and India have almost tripled their share of the global economy and increased their absolute economic size almost six times over. In 2060, China and India's share of global GDP looks set to surpass the combined share of GDP from today's most industrialized countries. This fundamental shift in the world's centre of economic gravity will lead to a significant shift in power away from Western countries. This is one scenario that has been forecast by the OECD, a Paris based think-tank, in an article titled: Looking to 2060: Long-term global growth prospects. The composition of global GDP will change significantly between now and 2060. Average income levels in China and India will be closer to the average incomes in OECD countries, and the share of global GDP coming from China and India will surpass the combined income of all OECD member countries in 2060. Meanwhile, Europe and America's share of total GDP will decline sharply, from 40 per cent in 2011 to only 25 per cent in 2060.China's share of the world economy is set to go from 17 per cent to 28 per cent in 2060. In contrast, America's share of global GDP will decline from 23 per cent to 16 per cent. So in not much more than a decade, there will be a huge

* This is an edited and expanded version of presentation at the Faculty of International Relations and Political Studies, University of Lodz, March 21, 2012. 
transformation in the structure of regional and world power, not only economic weight but also the political power that inevitably follows economic power in some form or other.

It is clear that the global power map is shifting in response to these trends. Prior to the recent financial and economic crisis, the forum of choice for dealing with such matters was the Group of Eight (G-8) nations, the informal collection of nations that supposedly represented the major global economic powers. Only one of those nations, Japan, was an Asian nation. Since the crisis, the G-8 has given way to a new informal grouping, the G-20. Six of these 20 now come from Asia - China, Japan, South Korea, India, Indonesia and Australia. The fact that both the G-20 Summit and the Nuclear Security Summit were recently hosted in South Korea symbolizes Asia's importance to the international system. The emerging economies of Asia are emerging no longer - they have emerged, and they are "surging." And their growth will drive the global economy.

The impressive and undeniable rise of Asia has led to suggestions that the West is losing its global leadership and needs to recognize Asia's looming superiority. One of the most prominent voices of such "triumphalism" is Kishore Mahbubani, Professor in the Practice of Public Policy and Dean of the Lee Kuan Yew School of Public Policy at the National University of Singapore. In The New Asian Hemisphere, Kishore Mahbubani argues that Western minds need to step outside their "comfort zone" and prepare new mental maps to understand the rise of Asia. The West, he says, must gracefully share power with Asia by giving up its automatic domination of global institutions from the IMF to the World Bank, from the G7 to the UN Security Council. Only then will the new Asian powers reciprocate by becoming responsible stakeholders in a stable world order. $\mathrm{He}$ argues that today's great question is whether the West will accommodate itself to the rise of Asia - and that there are reasons to worry that it will not. What troubles Mahbubani is the seeming unwillingness of Western states to give up global domination and share power gracefully. As he sees it, U.S. and European leaders simply cannot quite believe that world order could improve in the absence of the West's supremacy. The result is a growing rift between a self-centered West and the rest of humanity, which no longer sees the Euro-Atlantic world as the custodian of global civilization.

At first glance Asia's rise and vitality do contrast sharply with Europe's current predicament.

Not surprisingly, many people conclude that Europe is a spent force. And it's not only people in emerging economies who think so. A Transatlantic Trends poll showed that last year, for the first time, a slight majority of Americans feel that Asian countries were more important to their country's national interests than were the countries of the EU. At the same time a Pew Global Attitudes Survey pointed out that $63 \%$ of Chinese, $65 \%$ of Britons and even $46 \%$ of Americans believe China will soon be the world's leading superpower - indeed, many think it has already taken over from the US in that respect. 


\section{Asia's challenges}

At the same time, any caricature of the economic present that depicts a steadily declining Europe and a uniformly prosperous Asia would be, at best, highly incomplete. Europe's present is challenging certainly. Parts of our Union are facing painful adjustments to a new economic reality. But Europe as a whole remains strong in many respects, not least in our continuing competitiveness in matters of international trade and investment.

Asia is nowhere near closing its economic and military gap with the West. The region produces roughly 30 percent of global economic output, but because of its huge population, its per capita GDP is only $\$ 5,800$, compared with $\$ 48,000$ in the United States. Asian countries are furiously upgrading their militaries, but their combined military spending in 2008 was still only a third that of the United States. Even at current torrid rates of growth, it will take the average Asian 77 years to reach the income of the average American. The Chinese need 47 years. For Indians, the figure is 123 years. And Asia's combined military budget won't equal that of the United States for 72 years.

Given Asia's relatively low per capita income, its growth rate will indeed outpace the West's for the foreseeable future. But the region faces enormous demographic hurdles in the decades ahead. More than 20 percent of Asians will be elderly by 2050. Aging is a principal cause of Japan's stagnation. China's elderly population will soar in the middle of the next decade. Its savings rate will fall while healthcare and pension costs explode. India is a lone exception to these trends-any one of which could help stall the region's growth.

Environmental and natural resource constraints could also prove crippling. Asia's diverse environment is under growing pressure as a result of population growth, economic development and climate change. Asia thus faces enormous environmental challenges. It is acknowledged that economic growth has led to widespread degradation of the environment in Asia. Furthermore, Asia now emits some $30 \%$ of worldwide greenhouse gases, which on the basis of current trends would reach over $40 \%$ by 2030 . In a region that contributes considerably to global greenhouse gas emissions and is, at the same time, highly vulnerable to the effects of climate change, work and dialogues on climate change mitigation as well as adaptation are necessary, and are thus, of course, included in our national and regional programs . Pollution is worsening Asia's shortage of fresh water while air pollution exacts a terrible toll on health (it kills almost 400,000 people each year in China alone). Without revolutionary advances in alternative energy, Asia could face a severe energy crunch. Climate change could devastate the region's agriculture.

The two rising powers- China and India experience huge domestic challenges. Doubts are expressed about the sustainability of China's growth model. It is suggested that "low hanging fruit" reforms and the benefits from harnessing 
previously wasted labor resources have been largely exhausted. Experts refer to a series of deeply embedded "second generation" development challenges facing China, including poverty (especially rural poverty), income inequality, stressed and depleted natural resources, and other environmental challenges. Failure to address major environmental and development problems in China in the medium to longer term could disrupt the development and stability of China and the region. There are a number of constraints on India's potential growth: high rates of rural and urban poverty; corruption; caste-related violence; unresolved border disputes; and deficient rural and urban infrastructure (particularly electricity, roads, railways, ports, airports, telecommunications, water and sanitation).

Importantly, as Minx in Pei convincingly argues in his article "Thing Again: Asia's Rise" in Foreign Policy (July/August 2009) there's little real evidence to suggest that the rise of Asia comes from a mysteriously successful form of Asian capitalism. The truth is more mundane: The region's dynamism owes a great deal to its strong fundamentals (high savings, urbanization, and demographics) and the benefits of free trade, market reforms, and economic integration. Asia's relative backwardness is a blessing in one sense: Asian countries have to grow faster because they're starting from a much lower base.

Asian capitalism does have three unique features, but they do not necessarily confer competitive advantages. First, Asian states intervene more in the economy through industrial policy, infrastructural investment, and export promotion. But whether that has made Asian capitalism more dynamic remains an unresolved puzzle. The World Bank's classic 1993 study of the region, "The East Asian Miracle," could not find evidence that strategic intervention by the state is responsible for East Asia's success. Second, two types of companies-family-controlled conglomerates and giant, state-owned enterprises-dominate Asia's business landscape. Although such corporate ownership structures enable Asia's largest companies to avoid the short-termism of most American firms, they also shield them from shareholders and market pressures, making Asian firms less accountable, less transparent, and less innovative.

Autocracies, mainly in East Asia, may seem to have made their countries prosperous. The so-called dragon economies of South Korea, Taiwan, Singapore, Indonesia under Suharto, and now China experienced their fastest growth under nondemocratic regimes. Frequent comparisons between China and India appear to support the view that a one-party state unencumbered by messy competitive politics can deliver economic goods better than a multiparty system tied down by too much democracy. But Asia also has had many autocracies that have impoverished their countries-consider the tragic list of Burma, Pakistan, North Korea, Laos, Cambodia under the murderous Khmer Rouge, and the Philippines under Ferdinand Marcos.

Asia is pouring money into higher education. But Asian universities will not become the world's leading centers of learning and research anytime soon. None of the world's top 10 universities is located in Asia, and only the University 
of Tokyo ranks among the world's top 20. In the last 30 years, only eight Asians, seven of them Japanese, have won a Nobel Prize in the sciences. The region's hierarchical culture, centralized bureaucracy, weak private universities, and emphasis on rote learning and test-taking will continue to hobble its efforts to clone the United States' finest research institutions.

Even Asia's much-touted numerical advantage is less than it seems. China supposedly graduates 600,000 engineering majors each year, India another 350,000 . The United States trails with only 70,000 engineering graduates annually. Although these numbers suggest an Asian edge in generating brainpower, they are thoroughly misleading. Half of China's engineering graduates and two thirds of India's have associate degrees. Once quality is factored in, Asia's lead disappears altogether. A much-cited 2005 McKinsey Global Institute study reports that human resource managers in multinational companies consider only 10 percent of Chinese engineers and 25 percent of Indian engineers as even "employable," compared with 81 percent of American engineers.

\section{Europe and Asia: opportunities and gaps}

Whether it's over blown or not, Asia is poised to increase its geopolitical and economic influence rapidly in the decades to come. It has already become one of the pillars of the international order. Asia's rise should present more opportunities than threats. The region's growth not only has lifted hundreds of millions out of poverty, but also will increase demand for Western products. Asia's rise also provides the competitive pressures urgently needed for America and Europe to get their own houses in order.

EU-Asia trade is booming today and is crucial both for Europe's economic recovery and ensuring that Asian growth remains on track. Just two decades ago, China and the EU traded almost nothing. Today, it is second-largest economic partnership in the world. The EU-Korea free trade agreement is the first in a series of trade-expanding deals that Europe is negotiating with Asian partners. Europe is the biggest source of foreign investments in Asia. Today, the Eurozone crisis has made Europe's frontier-free single market even more of a magnet for Asian investors. A recent survey underlined that 45 percent of businesses in Asia are either currently doing or looking to make strategic acquisitions in Europe in the next 12 months, compared with just 14 percent in the Middle East and 7 percent in North America.

Neither Europe nor Asia can work alone to tackle threats to global stability that include resource competition, nuclear proliferation, overpopulation and climate change. Europe isn't indifferent and certainly not irrelevant to Asia's rise. As the United States speaks of the Asia Pacific Century and seems to reinforce its presence in Asia, Europe must develop its own blueprint for improved engagement with the region. 
The Asia-Europe Meetings (ASEM) process is a healthy, expanding and promising process for enhanced Europe-Asia relations as evidenced by the widening number of sectors involved and the growing number of members. ASEM is a continual dialogue between Asian and European governments. During the periods between Summits and Foreign Ministers' Meetings, inter-governmental ministerial, senior official and expert meetings maintain the momentum. ASEM is informal and multi-sectoral, and thus able to address global issues and challenges. ASEM also brings together educators and researchers. One key achievement of ASEM is co-funded by the Commission: the Trans-Eurasia Information Network (TEIN), the first large-scale research and education internet-based network connecting regional researchers in Asia with their counterparts in Europe.

In addition, ASEM brings together non-governmental stakeholders. Civil society groups, parliamentarians and the business community meet at the Asia-Europe People's Forum, Asia-Europe Parliamentary Partnership and Asia-Europe Business Forum held every two years alongside ASEM Summits. The Singapore-based Asia-Europe Foundation (ASEF) is funded by all ASEM partners (with about $25 \%$ coming from the Commission) and promotes understanding and collaboration between the peoples of Asia and the EU through cultural, intellectual and people-to-people exchanges. The Foundation's outreach to civil society and the wider public complements the ASEM dialogues, and the Info-Board internet site provides transparency on the ASEM process.

The EU could engage more strongly with South Asian and Southeast Asian countries on foreign policy and security questions, not just trade. This means top-level EU participation in Asian security fora such as the ASEAN Regional Forum, or ARF. It means showing up and seriously participating in ministerial meetings with Asian countries such as the EU-ASEAN gathering of foreign ministers in Brunei in April. It also requires regular and consistent high-level conversations on global and regional challenges with India and other South Asian nations.

Apart from trips to China, EU foreign policy chief Catherine Ashton has been a rare visitor to the rest of Asia. Her decision to stay away from the ARF in 2011, for a second year running, was a serious faux pas. And surprisingly, Asians have put Europe's request to join the East Asia Summit - the region's prime security club - on hold and insist that Europeans must first prove they are ready for a serious conversation with Asia on security. European policymakers are selling Europe short. Asia cannot take Europe seriously unless it does a better job of communicating with the region - and gains better understanding of what makes increasingly self-confident Asians tick.

Dealing with a changing and rising Asia will require that the EU engages in new courtships and new alliances with governments, businesses and civil society leaders in the region. By failing to engage seriously and consistently with Asia, Europeans are propagating a myth of European weakness and irrelevance. Europeans retain a somewhat one-dimensional vision of Asia's rise and consider 
the region to be a place of economic opportunities. But the wave of disputes over islands and rocks between China and its neighbors is evidence of dangerous undercurrents in Asia.

Recently, though, Brussels has taken greater notice of the broader issues. High Representative Catherine Ashton says she is in the middle of an 'Asian Semester' as she attends different regional meetings and wants to label the EU as an 'Asian partner.' All the member states in the Union recently signed up to new guidelines for European policy in East Asia, including on difficult issues such as the South China Sea. And at the last ASEAN Regional Forum, Ashton teamed up with US Secretary of State Hillary Clinton on joint cooperation in Asia.

EU-ASEAN relations stand at an interesting new point, with the two parties poised to increase cooperation. In the past, the EU and ASEAN have been divided on how to approach Burma, with Europeans clamoring for sanctions and ASEAN insisting on quiet diplomacy. As reform gets underway in Burma, the EU and ASEAN can work together to create development opportunities there. The EU recently upgraded its presence in Burma, which bodes well for cooperation.

\section{Learning from the US experience}

In the fall of 2011 and early 2012, Barack Obama's administration announced it would be intensifying the US role in the Asia-Pacific region. As the American president stated in a November 2011 address to the Australian parliament, "The United States will play a larger and long-term role in shaping this region [the Asia-Pacific] and its future." The Obama administration's increased emphasis on the Asia-Pacific region appears to have been prompted by four major developments:

- Growing economic importance of the Asia-Pacific region, particularly China, to the United States' economic future;

- China's growing military capabilities and its increasing assertiveness of claims to disputed maritime territory, with implications for freedom of navigation and the United States' ability to project power in the region;

- The winding down of US military operations in Iraq and Afghanistan; and

- Efforts to cut the US federal government's budget, particularly the defense

- budget, which threaten to create a perception in Asia that the US commitment to

- the region will wane. ${ }^{2}$

${ }^{1}$ The White House Office of the Press Secretary, Remarks by President Obama to the Australian Parliament, (November 17, 2011), http://www.whitehouse.gov/the-press-office/2011/11/17/ remarks-president-obama-australian-parliament.

2 Pivot to the Pacific? The Obama Administration's "Rebalancing" Toward Asia, "Congressional Research Service" 2012,March 28, http://www.fas.org/sgp/crs/natsec/R42448.pdf. 
Obama administration has announced six key lines of action: strengthening bilateral security alliances; deepening working relationships with emerging powers, including China; engaging with regional multilateral institutions; expanding trade and investment; forging a broad-based military presence; and advancing democracy and human rights. ${ }^{3}$

America's treaty alliances with Japan, South Korea, Australia, the Philippines, and Thailand will remain the fulcrum for its strategic turn to the Asia-Pacific. The alliances have leveraged the United States' regional presence and leadership, but need to be updated for a changing world. In this effort, the Obama administration is guided by three core principles: Maintain political consensus on the core objectives of the alliances, ensure that the alliances are nimble and adaptive so they can successfully address new challenges and seize new opportunities, and guarantee that the defense capabilities and communications infrastructure of the alliances are operationally and materially capable of deterring provocation from the full spectrum of state and non-state actors.

The United States and Japan have agreed to a new arrangement, including a contribution from the Japanese government of more than $\$ 5$ billion, to ensure the continued, enduring presence of American forces in Japan, while expanding joint intelligence, surveillance, and reconnaissance activities to deter and react quickly to regional security challenges, as well as information sharing to address cyber threats. The most acute problem in U.S.-Japan relations is in Okinawa, which hosts 80 percent of the US military facilities in Japan. Efforts by the US and Japanese governments to reduce that footprint have been problematic and are in the process of difficult negotiations.

The United States and the Republic of Korea have agreed on a plan to ensure the successful transition of operational control to Seoul during wartime and have ensured a successful passage of the Korea-US Free Trade Agreement. The United States welcomes South Korea's growing regional and international role and the ROK government's efforts to realize the "Global Korea" vision expanding its global reach to be commensurate with its economic status. Washington and Seoul continue to hold regular joint military exercises to enhance extended deterrence, interoperability, and the readiness of alliance forces. In budgetary terms, the number of US troops sustained both in Japan and Korea, may, over time, prove to be more of a drain on US flexibility. In the case of South Korea, there have been concerns in the United States about the high cost of measures to move US military units to more defensible facilities away from the demilitarized zone.

The alliance with Australia has been evolving from a Pacific partnership to an Indo-Pacific one. Washington and Canberra closely consult with each other on key regional issues and ways to strengthen the regional architecture

3 "America's Pacific Century", Op-Ed, Hillary Rodham Clinton, Secretary of State, "Foreign Policy Magazine" 2011, October 11, http://www.state.gov/secretary/rm/2011/10/175215.htm. 
in the Asia-Pacific. Washington and Canberra are considering an increased combined naval presence and capabilities to respond more readily to humanitarian disasters; improved Indian Ocean facilities and expanded training exercises for amphibious and land operations. Within Australia itself, there is a vigorous debate on increased military cooperation with the United States, and particularly on the deployment of 2,500 US Marines in Australia. The critics believe that the US Marines' deployment decision will have deep consequences for Australia's relations with China, and that, in Washington and in Beijing, this will be seen as Australia aligning itself with an American strategy to contain China.

Alliances with the Philippines and Thailand are also being enhanced, but pose more serious challenges. Washington is increasing the number of ship visits to the Philippines, assisting Manila in naval modernization and working to ensure the successful training of Filipino counterterrorism forces. In Thailand, America's oldest treaty partner in Asia, the two countries are working to establish a hub of regional humanitarian and disaster relief efforts.

The United States could be drawn into a China-Philippines conflict because of its 1951 Mutual Defense Treaty with the Philippines. American officials insist that Washington does not take sides in the territorial dispute in the South China Sea and refuse to comment on how the United States might respond to Chinese aggression in contested waters. An apparent gap exists between American views of U.S. obligations and Manila's expectations. Senior Filipino politicians publicly criticized the United States over its "silence" on the Scarborough Shoal standoff between Philippine Navy and Chinese fishing vessels on April 8, 2012.

The political instability in Thailand and diverging strategic priorities have contributed to some degree of drift in the overall US-Thailand relationship. Although the alliance remains central to Thailand's foreign policy, and the United States reiterates the strategic value of Thailand's military facilities, observers on both sides point to unease. The Obama administration's emphasis on building stronger relations with Indonesia signals to some Thai observers that Thailand is being displaced as the chief US partner in the region. Differing threat perceptions about China, and Thailand's increased military cooperation with Beijing, also contribute to a sense that the alliance, while institutionally sound, suffers from a lack of strategic alignment. ${ }^{4}$

America's outreach to China, India, Indonesia, Singapore, New Zealand, Malaysia, Mongolia, Vietnam, Brunei, and the Pacific Island countries is all part of a broader effort to ensure a more comprehensive approach to American strategy and engagement in the region. Increased interactions with India and Indonesia are particularly notable, given the rapidly rising regional influence of the two nations.

${ }^{4}$ Thailand: Background and U.S. Relations, Congressional Research Service (February 8, 2012), http://www.fas.org/sgp/crs/row/RL32593.pd. 
The Obama administration has expanded its bilateral partnership with India; actively supports India's Look East efforts; and has outlined a new vision for a more economically integrated and politically stable South and Central Asia, with India as a linchpin. In recent years, the United States and India have significantly broadened their defense cooperation, as demonstrated by a robust engagement in bilateral dialogues, military exercises, and personnel exchanges, as well as nearly $\$ 9$ billion in defense trade since 2008. There is, however, strong feeling in Washington that India has made no corresponding gesture in return for the big vision that presidents Obama and Bush have offered the Indian leadership and that India is still quite ambiguous about the priority it places on its future with the United States. India is expected to be more supportive on difficult issues, such as Iran, and also on Afghanistan, where key differences seem to have emerged between the United States and India regarding the political endgame. ${ }^{5}$

The United States and Indonesia have resumed joint training of Indonesian special forces and signed a number of agreements on health, educational exchanges, science and technology, and defense. Indonesia's adoption of a new democratic foreign-policy plank creates opportunities for the U.S. and Indonesia to cooperate on democracy-promotion efforts. However, the two countries are still caught up in bureaucratic impediments, lingering historical suspicions, and gaps in understanding each other's perspectives and interests. ${ }^{6}$ Human Rights activists voice worries about alleged abuses by Kopassus, particularly in West Papua, and challenge Washington's assertion that the special forces have undergone, as the new Pacific Command Commander Admiral Samuel Locklear put it, a "near-complete transformation."

One of the most visible changes in the United States' regional policies has been the Obama administration's decision to fully engage the region's multilateral institutions as a way of supplementing, but not supplanting, America's important bilateral ties. The United States has opened a new US mission to ASEAN in Jakarta and signed the Treaty of Amity and Cooperation with ASEAN. The United States joined the East Asia Summit, and Obama participated in its November 2011 meeting. While Washington is displaying more patience with the regional pace of regionalism, it continues to focus on developing a more results-oriented agenda, especially in efforts to address disputes in the South China Sea. The United States considers APEC the Asia-Pacific's premier regional economic institution, which has become even more important in terms of helping expand US exports and create and support high-quality jobs in the United States.

${ }^{5}$ R. N. Burns, India Lets U.S. Down on Iran, "Indian Defence” 2012, February 20, http:// www.indiandefence.com/forums/f5/india-lets-u-s-down-iran-14968.

${ }^{6}$ A. M. Murphy, Democratization and Indonesian Foreign Policy: Implications for the United States, “Asia Policy” 2012, January 13, http://nbr.org/publications/element.aspx?id=573.

${ }^{7}$ Nomination of Admiral Samuel J. Locklear to be Commander of the U.S. Pacific Command, Committee on Armed Services, U.S. Senate (February 9, 2012), http://armed-services.senate.gov/ Transcripts/2012/02\%20February/12-01\%20-\%202-9-12.pdf. 
At the same time, the increased interest in regional multilateralism poses new challenges for the United States in terms of prioritizing its level of participation in these organizations, as well as allaying emerging fears that the major powers are likely to undermine the ASEAN's current central role in regional institution building. The United States' absence in some of the regional groupings and organizations, such as ASEAN+3 (APT) or the Shanghai Cooperation Organization, is seen by some as potentially problematic and marginalizing the United States' role in time.

Economics and trade are both causes of and instruments for the pivot toward the Asia-Pacific. The region plays a crucial role in Obama's National Export Initiative. Four of the 10 emerging export markets targeted in the 2011 National Export Strategy, China, India, Indonesia, and Vietnam, are part of the Asia-Pacific region. In 2011, American exports to the Pacific Rim totaled \$320 billion, supporting 850,000 American jobs.

The United States' regional trade policy combines promotion of bilateral free agreements with participation in the multilateral Trans-Pacific Partnership (TPP), which brings together economies from across the Pacific, developed and developing alike, into a single trading community. The United States' leadership role in TPP is an important element of its reassurance of being a major force in the region's economic and geopolitical dynamics.

The negotiation process for the TPP is, however, facing serious challenges, with the United States encountering resistance to its proposals regarding intellectual property rights and investor-state disputes. Some of the countries are pushing the United States to offer greater access to US markets, particularly agricultural markets, such as dairy products and sugar. It is also unclear what impact the TPP will have on US interest and participation in APEC. It appears that the administration regards the former as the lead entity, with the latter a forum for exploring topics that traditionally have not been part of trade agreements. ${ }^{8}$

One of the most glaring things about TPP it is that it does not include China, Asia's biggest trading nation. That could be, as US officials say, because China, with its state-owned enterprises, piratical tendencies and questionable currency policy, is not yet ready to join such a high-level agreement. The critics, however, counter-argue that Vietnam, hardly a paragon of free-market capitalism, is one of nine negotiating countries. They assert that America's design for Asian trade is inspired by the goal of containing China, and the TPP template effectively excludes its membership. ${ }^{9}$

Despite the reductions in planned levels of US defense spending, the United States intends to maintain and strengthen its military presence in the Asia-Pacific. This element of the pivot to Asia has understandably been the most controversial.

${ }^{8}$ Pivot to the Pacific? The Obama...

9 J. Bhagwati, America's Threat to Trans-Pacific Trade, "Project-Syndicate" 2011, December 30, http://www.project-syndicate.org/commentary/america-s-threat-to-trans-pacific-trade. 
China and many regional experts see it as primarily driven by the rise of China's military power. Washington's interpretation of the new defense strategy is much broader. It is argued, for example, that the importance of U.S. economic interests in the Asia-Pacific region has significant security and military implications. With an increasing volume of U.S. exports and imports flowing in and out of the region, it has become critical that the United States maintains free navigation from the Arabian Sea across to the eastern edge of the Pacific Ocean.

Publicly, the Obama administration has been assuring the region that, even more than America's military might or the size of its economy, the United States' most potent asset is its "steadfast support for democracy and human rights." However, the current U.S. administration's more pragmatic and less ideological international and regional stance, compared to the previous U.S. administration's, has toned down Washington's rhetoric in support of democracy and human rights. The changed style also confirms that the United States does not want to complicate its bilateral relations with China, a notorious violator of human rights. At the same time, as the recent, unprecedented developments in Burma indicate, a more subtle support of democracy and human rights in conjunction with geopolitical calculations, such as leveraging the Burmese military junta's fear of overdependence on China, as well as improved consultations with regional actors, such as ASEAN, can be much more effective in promoting democracy and human rights. While managing democratic aspirations in Burma and in the region broadly will continue to present challenges to current and future US administrations, there are already signs of a possible "domino effect" of Burma's opening. The Vietnamese leadership, for example, seems to be disturbed by developments in Burma. With Burma looking less and less like a police state, Hanoi fears unwanted scrutiny. If Burma improves on human rights and gets rewarded, Vietnam would need to meet the same standards," notes Carl Thayer, a Vietnam expert at the Australian Defense Force Academy. ${ }^{10}$

\section{Conclusion}

A favorite theme in international debate nowadays is whether Asia's rise signifies the West's decline. But the current focus on economic malaise in Europe and the United States is distracting attention from the many serious challenges that call into question Asia's continued success. To be sure, today's ongoing global power shifts are primarily linked to Asia's phenomenal economic rise, the speed and scale of which have no parallel in world history. With the world's fastest-growing economies, fastest-rising military expenditures, fiercest resource

${ }^{10}$ D. Roasa, The Terrible Tiger, "Foreign Policy" 2012, April 17, http://www.foreignpolicy. com/articles/2012/04/17/the_terrible_tiger\#.T5DESdPssm0.email. 
competition, and most serious hot spots, Asia obviously holds the key to the future global order. But Asia faces major constraints. It must cope with entrenched territorial and maritime disputes, such as in the South China Sea; harmful historical legacies that weigh down its most important interstate relationships; increasingly fervent nationalism; growing religious extremism; and sharpening competition over water and energy. Moreover, Asia's political integration badly lags behind its economic integration, and, to compound matters, it has no security framework. Regional consultation mechanisms remain weak. Differences persist over whether a security architecture or community should extend across Asia, or be confined to an ill-defined "East Asia."

More broadly, Asia's power dynamics are likely to remain fluid, with new or shifting alliances and strengthened military capabilities continuing to challenge regional stability. For example, as China, India, and Japan maneuver for strategic advantage, they are transforming their mutual relations in a way that portends closer strategic engagement between India and Japan, and sharper competition between them and China. The future will not belong to Asia merely because it is the world's largest, most populous, and fastest-developing continent. Size is not necessarily an asset. Asia's challenges are graver than those facing Europe, which embodies comprehensive development more than any other part of the world. Despite China's aura of inevitability, it is far from certain that Asia, with its pressing internal challenges, will be able to spearhead global growth and shape a new world order. 